\title{
Aging and cerebrovascular lesions in pure and in mixed neurodegenerative and vascular dementia brains: a neuropathological study
}

\author{
Jacques De Reuck, Claude-Alain Maurage, Vincent Deramecourt, Florence Pasquier, Charlotte Cordonnier, \\ Didier Leys, Regis Bordet \\ Université Lille 2, INSERM U1171, Degenerative \& Vascular Cognitive Disorders, CHR Lille, F-59000, France
}

\begin{abstract}
Introduction: The prevalence of dementia is increasing in our aging population. Because of the complexity of disease pathology, dementia classifications remain controversial. The present post-mortem study investigates whether there are age differences between dementia brains with a single pure neurodegenerative or cerebrovascular disease and those with mixed pathological features. Also, the impact of these vascular lesions is compared.

Material and methods: A total of 132 dementia brains with a pure neurodegenerative or cerebrovascular disease and 84 with mixed features were examined. Main age and gender distribution were compared between the overall group of pure and of mixed dementia. Also, the most common subgroups were compared separately. In addition to the detection of macroscopic visible lesions, a whole coronal section of a cerebral hemisphere, at the level of the mamillary body, was taken for semi-quantitative microscopic evaluation of white matter changes (WMCs), cortical micro-bleeds (COMBs), and cortical micro-infarcts (COMIs).

Results: Overall, patients with mixed dementia were at death significantly older than those with pure dementia. According to the main diagnosis, the pure forms of Alzheimer's disease (AD) and frontotemporal lobar degeneration (FTLD) were more common in the younger age groups while in the older ones the mixed form of Lewy body disease (LBD) predominated. Neuropathological examination revealed an increased severity of cerebral amyloid angiopathy (CAA), territorial infarcts, lobar haematomas, and CoMIs in the mixed AD group. In FTLD only CoMIs were increased in the mixed group, while in LBD no differences in severity of all cerebrovascular lesions were observed. Lacunar infarcts were more frequent in pure vascular dementia, while CAA predominated in the mixed one.

Conclusions: Mixed dementia during the aging process is mainly due to the severity of $A D$ and $L B D$ pathologies combined with CAA-related cerebrovascular lesions.
\end{abstract}

Key words: neuropathology, aging, cerebrovascular lesions, pure and mixed dementia syndromes, Alzheimer's disease, frontotemporal lobar degeneration, Lewy body disease, vascular dementia. 


\section{Introduction}

The prevalence of dementia is increasing in our aging population. Because of the complexity of disease pathology, dementia classifications remain controversial [32]. Many distinct brain diseases other than Alzheimer's disease (AD) afflict older human patients and contribute to cognitive impairment [2,31]. Dementia of unknown aetiology increases with age [8]. Mixed brain pathologies account for most dementia cases in the elderly [25,34]. The most common mixed dementia is the coexistence of $A D$ with cerebrovascular pathology [26]. Cerebral amyloid angiopathy (CAA) occurs with increasing age and is the cause that contributes most to this type of mixed dementia $[25,27]$. The second most frequent mixed dementia is the association of AD with Lewy body disease (LBD) [26]. Cerebrovascular lesions are also frequently observed in this type of mixed dementia [17,35].

The present post-mortem study investigates whether there are age differences between dementia brains with a single "pure" neurodegenerative or cerebrovascular disease and those with mixed pathological features. Also, the impact of cerebrovascular lesions is compared in the different pure and mixed disease entities.

\section{Material and methods}

A total of 216 demented patients, who had been followed up at the Lille University Hospital, underwent an autopsy. Early obtained informed consent of

Table I. Percentage distribution of the different types of mixed dementia

\begin{tabular}{|lc|}
\hline Type of mixed dementia & $\%$ \\
\hline Alzheimer's disease with cerebrovascular pathology & 36 \\
\hline Alzheimer's disease with Lewy body pathology & 24 \\
\hline Vascular dementia with Alzheimer pathology & 15 \\
\hline Lewy body disease with Alzheimer pathology & 14 \\
\hline $\begin{array}{l}\text { Amyotrophic lateral sclerosis with frontotemporal } \\
\text { lobe pathology }\end{array}$ & 3 \\
\hline $\begin{array}{l}\text { Frontotemporal lobe degeneration with Alzheimer } \\
\text { pathology }\end{array}$ & 3 \\
\hline \begin{tabular}{l} 
Lewy body disease with cerebrovascular pathology \\
\hline $\begin{array}{l}\text { Frontotemporal lobe degeneration with } \\
\text { cerebrovascular pathology }\end{array}$
\end{tabular} & 2 \\
\hline $\begin{array}{l}\text { Progressive supranuclear palsy with cerebrovascular } \\
\text { pathology }\end{array}$ & 1 \\
\hline
\end{tabular}

the patients, or from the closest family later, allowed the autopsy for diagnostic and scientific purposes. The brain tissue samples were acquired from the Neuro-Bank of Lille University, federated to the "Centre des Resources Biologiques", which acted as an institutional review board.

In total, 132 brains with a pure neurodegenerative or cerebrovascular disease and 84 with mixed features were examined. Main age and gender distribution were compared between the overall pure groups and between the most common subgroups according to their main diagnosis. The low number of patients with progressive supranuclear paralysis (PSP), amyotrophic lateral sclerosis (ALS) and corticobasal degeneration (CBD) did not allow a separate statistical comparison between the pure and the mixed cases. Table I shows the percentage distribution of the different types of mixed dementia.

Alzheimer's disease features were classified according to the Braak and Braak criteria [3]. The main diagnosis of $A D$ was retained when stages $V$ and $V I$ were reached. In mixed dementia groups, beneath the main diagnosis, additional $A D$ features were retained when stages II to IV were already reached. The CERAD criteria were used to evaluate the severity of CAA [20]. The degree of CAA was evaluated semi-quantitatively on four cortical samples and graded from 0 to 3. The post-mortem diagnosis of frontotemporal lobar disease (FTLD) was made according to the neuropathological diagnostic and the nosological criteria of the Consortium for FTLD [5]. FUS histochemistry was performed in tau- and TDP-negative cases. LBD was diagnosed according to the report of the consortium on DLB international workshop [31]. Progressive supranuclear palsy (PSP) was retained according to the NIND criteria [22]. The neuropathological criteria proposed by Cruz-Sánchez et al. were used for the diagnosis of ALS [7]. The diagnosis of CBD was made according to the recommendations of an international consortium group [1]. Staging of the cerebrovascular pathology in pure and mixed vascular dementia (VaD) was performed according to the recommendations of the vascular dementia group [30].

In addition to the detection of macroscopic visible lesions such as haematomas, and territorial and lacunar infarcts, a whole coronal section of a cerebral hemisphere, at the level of the mamillary body, was taken for semi-quantitative microscopic evaluation of the small cerebrovascular lesions such as white matter changes (WMCs), cortical micro-bleeds (CoMBs), cortical 
micro-infarcts (CoMls), and lacunes. The mean values of WMCs were the average of the ranking scores: no change (RO), a few isolated (R1), frequently scattered in the corona radiata (R2), and forming confluent lesions (R3) of myelin and axonal loss. For the other cerebrovascular lesions their mean values corresponded to their average numbers in the individual brains [21].

Univariate comparisons of unpaired groups were performed with the Fisher's exact test for categorical data. The non-parametric Mann-Whitney U-test was used to compare continuous variables. The significance level, two-tailed, was set at $\leq 0.05$ for moderately significant, at $\leq 0.01$ for significant, and at $\leq 0.001$ for highly significant.

\section{Results}

Overall, patients with mixed dementia were, at death, significantly older than those with pure demen- tia, with $77(S D=10)$ years in the former and with 72 $(S D=11)$ years in the latter group $(p \leq 0.01)$, while male gender distribution was similar: $52 \%$ compared to $57 \%$. According to the age distribution, the mixed group consisted mainly of the oldest old $(p \leq 0.05)$, while adults were more frequent in the pure group $(p \leq 0.05)$. According to the main diagnosis FTLD was more common in the pure group $(p \leq 0.05)$ and LBD in the mixed group $(p \leq 0.01)$. The mixed dementia cases were mainly composed of an association of $A D$ with $\mathrm{VaD}$ and with LBD features. By comparing the cerebrovascular lesions between the overall pure and mixed groups, CAA $(p \leq 0.001)$ was found to be more severe and territorial infarcts $(p \leq 0.01)$, lobar haematomas $(p \leq 0.01)$, and CoMls $(p \leq 0.01)$ were more frequent in the latter group (Table II).

Comparing age and gender distribution in the subgroups, the main age of the mixed AD group was

Table II. Comparison of age distribution with standard deviation (SD), percentage main diagnosis, and severity of cerebrovascular features between pure and mixed dementia cases

\begin{tabular}{|c|c|c|}
\hline Items & Pure disease $(n=132)$ & Mixed disease $(n=84)$ \\
\hline Overall average age (years) & $72(\mathrm{SD}=11)$ & $77(\mathrm{SD}=10)^{\star \star}$ \\
\hline \multicolumn{3}{|l|}{$\%$ subgroups } \\
\hline Adult & 29 & - \\
\hline Young old & 42 & - \\
\hline Middle old & 21 & 32 \\
\hline Oldest old & 8 & $27^{*}$ \\
\hline Male gender (\%) & 57 & 52 \\
\hline \multicolumn{3}{|l|}{ Main disease (\%) } \\
\hline Alzheimer disease & 41 & 56 \\
\hline Frontotemporal lobar degeneration & $19^{*}$ & 7 \\
\hline Lewy body disease & 5 & $19^{* *}$ \\
\hline Progressive supranuclear palsy & 9 & 8 \\
\hline Amyotrophic lateral sclerosis & 9 & 8 \\
\hline Corticobasal degeneration & 3 & 0 \\
\hline Vascular dementia & 14 & 13 \\
\hline \multicolumn{3}{|l|}{ Cerebrovascular pathology } \\
\hline White matter changes & $0.7(0.9)$ & $1.0(1.1)$ \\
\hline Cerebral amyloid angiopathy & $0.3(0.7)$ & $1.2(1.3)^{\star \star \star *}$ \\
\hline Lacunar infarcts & $0.1(0.3)$ & $0.3(0.7)$ \\
\hline Territorial infarcts & $0.0(0.2)$ & $0.3(0.6)^{\star}$ \\
\hline Lobar haematomas & $0.0(0.2)$ & $0.3(0.6)^{\star}$ \\
\hline Cortical micro-infarcts & $0.2(0.7)$ & $1.0(2.1)^{\star \star}$ \\
\hline Cortical micro-bleeds & $0.0(0.3)$ & $0.2(0.7)$ \\
\hline
\end{tabular}

$p^{* \star *} \leq 0.001$ : highly significant, ${ }^{* *} p \leq 0.01$ : significant, ${ }^{*} p \leq 0.05$ : moderately significant 
greater than that of the pure group with, respectively, $77(S D=10)$ years and $69(S D=10)$ years $(p \leq 0.001)$, predominantly in the middle old group $(p \leq 0.0 .5)$. A similar age difference was observed between the FTLD groups with, respectively, $87(\mathrm{SD}=6)$ and $66(S D=10)$ years $(p \leq 0.001)$. Also, according to the age classification, mixed FTLD occurred more frequent- ly in the middle and oldest old patients $(p \leq 0.05)$ and more in the adult and the young old of the pure group ( $p \leq 0.001)$. No average age differences were observed between the pure and the mixed LBD, with, respectively, $78(\mathrm{SD}=3)$ years and $81(\mathrm{SD}=7)$ years, predominantly in the middle and oldest old of both groups. Also, in VaD no age differences were

Table III. Comparison of age with standard deviation (SD) and percentage of age subgroups and gender distribution according to the main diagnosis between the pure and the mixed dementia cases

\begin{tabular}{|c|c|c|}
\hline Items & $\begin{array}{l}\text { Pure disease } \\
\quad(n=132)\end{array}$ & $\begin{array}{l}\text { Mixed disease } \\
\quad(n=84)\end{array}$ \\
\hline Alzheimer's disease & $72(\mathrm{SD}=11)$ & $77(S D=10)^{\star \star}$ \\
\hline Overall age (years) & $69(S D=10)$ & $77(S D=10)^{\star \star}$ \\
\hline \multicolumn{3}{|l|}{$\%$ subgroups } \\
\hline Adult & 21 & 15 \\
\hline Young old & 32 & 21 \\
\hline Middle old & 26 & $43^{*}$ \\
\hline Oldest old & 21 & 21 \\
\hline Male gender (\%) & 66 & 40 \\
\hline \multicolumn{3}{|c|}{ Frontotemporal lobar degeneration } \\
\hline Overall age (years) & $66(S D=10)$ & $87(S D=6)^{\star * \star}$ \\
\hline \multicolumn{3}{|l|}{$\%$ subgroups } \\
\hline Adult & $32^{* \star *}$ & 0 \\
\hline Young old & $64^{* * *}$ & 0 \\
\hline Middle old & 4 & $33^{*}$ \\
\hline Oldest old & 0 & $67^{* *}$ \\
\hline Male gender (\%) & 65 & 66 \\
\hline \multicolumn{3}{|l|}{ Lewy body disease } \\
\hline Overall age (years) & $78(S D=3)$ & $81(S D=7)$ \\
\hline \multicolumn{3}{|l|}{$\%$ subgroups } \\
\hline Adult & 0 & 0 \\
\hline Young old & 0 & 0 \\
\hline Middle old & 67 & 50 \\
\hline Oldest old & 33 & 29 \\
\hline Male gender (\%) & 100 & 71 \\
\hline \multicolumn{3}{|l|}{ Vascular dementia } \\
\hline Overall age (years) & $76(S D=7)$ & $77(\mathrm{SD}=19)$ \\
\hline \multicolumn{3}{|l|}{ \% subgroups } \\
\hline Adult & 0 & 0 \\
\hline Young old & 31 & 33 \\
\hline Middle old & 53 & 34 \\
\hline Oldest old & 16 & 33 \\
\hline Male gender (\%) & 69 & 100 \\
\hline
\end{tabular}

$p^{* * *} \leq 0.001$ : highly significant, ${ }^{* *} p \leq 0.01$ : significant, ${ }^{*} p \leq 0.05$ : moderately significant 
observed, with $76(\mathrm{SD}=7)$ years in the pure and 77 $(\mathrm{SD}=19)$ years in the mixed cases. Gender distribution was similar in all the disease subgroups, except for the pure AD patients, in which a male predominance was seen $(p \leq 0.05)$ (Table III).

The neuropathological examination revealed an increased severity of CAA $(p \leq 0.001)$ and of territo- rial infarcts $(p \leq 0.01)$, lobar haematomas $(p \leq 0.01)$, and CoMls $(p \leq 0.001)$ in the mixed AD group with no differences in the severity of lacunar infarcts, WMCs, and CoMBs. In FTLD only CoMls were increased in the mixed group $(p \leq 0.05)$. In LBD no differences in severity of all cerebrovascular lesions were observed. In pure $\mathrm{VaD}$ the number of lacunar infarcts was sig-

Table IV. Comparison of the severity of cerebrovascular features between subgroups of pure and mixed dementia cases

\begin{tabular}{|c|c|c|}
\hline Items & Pure disease & Mixed disease \\
\hline \multicolumn{3}{|l|}{ Alzheimer disease } \\
\hline White matter changes & $0.8(0.9)$ & $1.2(1.1)$ \\
\hline Cerebral amyloid angiopathy & $0.4(0.1)$ & $1.7(1.3)^{\star \star \star}$ \\
\hline Lacunar infarcts & $0.1(0.4)$ & $0.2(0.9)$ \\
\hline Territorial infarcts & $0.0(0.1)$ & $0.4(0.5)^{\star \star}$ \\
\hline Lobar haematomas & $0.0(0.1)$ & $0.3(0.5)^{\star \star}$ \\
\hline Cortical micro-infarcts & $0.1(0.3)$ & $1.5(2.7)^{\star * \star}$ \\
\hline Cortical micro-bleeds & $1.0(0.9)$ & $1.2(1.1)$ \\
\hline \multicolumn{3}{|l|}{ Frontotemporal lobar degeneration } \\
\hline White matter changes & $1.0(1.0)$ & $1.0(1.0)$ \\
\hline Cerebral amyloid angiopathy & $0.0(0.0)$ & $0.0(0.0)$ \\
\hline Lacunar infarcts & $0.2(0.5)$ & $0.7(0.6)$ \\
\hline Territorial infarcts & $0.0(0.0)$ & $0.0(0.0)$ \\
\hline Lobar haematomas & $0.0(0.0)$ & $0.0(0.5)$ \\
\hline Cortical micro-infarcts & $0.0(0.0)$ & $0.7(0.6)^{\star}$ \\
\hline Cortical micro-bleeds & $0.8(0.9)$ & $1.0(1.0)$ \\
\hline \multicolumn{3}{|l|}{ Lewy body disease } \\
\hline White matter changes & $0.0(0.0)$ & $0.9(1.2)$ \\
\hline Cerebral amyloid angiopathy & $0.0(0.0)$ & $0.9(1.2)$ \\
\hline Lacunar infarcts & $0.0(0.0)$ & $0.1(0.4)$ \\
\hline Territorial infarcts & $0.0(0.0)$ & $0.1(0.3)$ \\
\hline Lobar haematomas & $0.0(0.0)$ & $0.1(0.5)$ \\
\hline Cortical micro-infarcts & $0.3(0.6)$ & $0.7(1.6)$ \\
\hline Cortical micro-bleeds & $1.7(1.2)$ & $1.2(1.3)$ \\
\hline \multicolumn{3}{|l|}{ Vascular dementia } \\
\hline White matter changes & $1.4(1.4)$ & $1.4(1.2)$ \\
\hline Cerebral amyloid angiopathy & $0.2(0.4)$ & $1.6(0.7)^{\star *}$ \\
\hline Lacunar infarcts & $1.6(1.7)^{\star * \star}$ & $0.2(0.4)$ \\
\hline Territorial infarcts & $0.8(1.0)$ & $0.7(0.8)$ \\
\hline Lobar haematomas & $0.2(0.4)$ & $0.0(0.0)$ \\
\hline Cortical micro-infarcts & $1.4(2.1)$ & $1.2(1.3)$ \\
\hline Cortical micro-bleeds & $1.7(0.9)$ & $1.4(0.5)$ \\
\hline
\end{tabular}

$p^{* * *} \leq 0.001$ : highly significant, ${ }^{* *} p \leq 0.01$ : significant, ${ }^{*} p \leq 0.05$ : moderately significant 
nificantly increased $(p \leq 0.01)$ while CAA predominated in the mixed form $(p \leq 0.001)$ (Table IV).

\section{Discussion}

The present study confirms that, overall, patients with mixed dementia are older than those with a pure neurodegenerative or cerebrovascular disease [24]. However, there are differences according to the disease type: mainly patients with AD and FTLD, who are the most frequent in this series, display this age difference, but not those with LBD and VaD.

$A D$ with $\operatorname{VaD}$ or $L B D$ features are the most frequent types of mixed dementia $[4,17,28]$.

The increase of CAA with age is the leading cause of mixed $A D$ group in elderly patients, leading to more frequent cerebral infarcts and lobar haematomas $[10,14,16-18,21,24]$.

Brains with FTLD display a low incidence of cerebrovascular lesions [11]. The reason why patients with FTLD and ALS have a favourable vascular risk profile is unknown [19]. The severe frontotemporal WMCs are related to the neurodegenerative disease itself and are not of vascular origin [12]. The increased number of CoMls in the mixed form, compared to the pure form of FTLD, is probably related to the much older age of the former [6].

Our study confirms that pure and mixed forms of LBD mainly occur in the middle old and the oldest old patients [34]. Pure and mixed LBD brains show a high incidence of CoMIs [14,17]. Additional AD features and CAA contribute less to the small cerebrovascular in LBD pathology $[13,15,35]$.

Different types of cerebrovascular lesions have already been described in pure $\mathrm{VaD}$ and mixed AD-VaD brains, with mainly lacunar infarcts in the former and severe CAA in the latter [16,17].

In conclusion, the older age of mixed dementia cases is mainly due the combination of the severity of the AD and LBD pathologies, and to CAA-related cerebrovascular lesions. This study argues again that mixed $A D-V a D$ has to be considered as the end stage of $A D[16]$.

\section{Disclosure}

The authors report no conflict of interest.

\section{References}

1. Amstrong MJ, Litvan I, Lang AE, Bak TH, Bhatia KP, Boronni B, Boxer AL, Dickson DW, Grossman M, Hallett M, Josephs KA, Kertesz A, Lee SE, Miller BL, Reich SG, Riley DE, Tolosa E, Troster AI,
Vidailhet M. Criteria for the diagnosis of corticobasal degeneration. Neurology 2013; 80: 496-503.

2. Attems J, Jellinger K. Neuropathological correlates of cerebral multimorbidity. Curr Alzheimer Res 2013; 10: 569-577.

3. Braak H, Braak E. Neuropathological staging of Alzheimer-related changes. Acta Neuropathol 1991; 82: 239-259.

4. Brenowitz WD, Keene CD, Hawes SE, Hubbard RA, Londstreth WT Jr, Woltjer RL, Crane PK, Larson EB, Kukull WA. Alzheimer's disease neuropathological change, Lewy body disease and vascular brain injury in clinic- and community-based samples. Neurobiol Aging 2017; 53: 83-92.

5. Cairns NJ, Bigio EH, Mackenzie IR, Neumann M, Lee VM, Hatanpaa KJ, White CL $3^{\text {rd }}$, Schneider JA, Grinberg LT, Halliday G, Duyckaerts C, Lowe JS, Holm IE, Tolnay M, Okamoto K, Yokoo H, Murayama S, Woulfe J, Munoz DG, Dickson DW, Ince PG, Trojanowski IQ, Mann DM. Consortium for Frontotemporal Lobar Degeneration. Neuropathologic diagnostic and nosologic criteria for frontotemporal lobar degeneration: consensus of the Consortium for Frontotemporal Lobar Degeneration. Acta Neuropathol 2007; 114: 5-22.

6. Chui HC, Ramirez Gomez L. Vascular contributions to cognitive impairment in late life. Neurol Clin 2017; 35: 295-323.

7. Cruz-Sánchez FF, Moral A, de Belleroche J, Rossi ML. Amyotrophic lateral sclerosis brain banking: a proposal to standardize protocols and neuropathological diagnostic criteria. J Neural Transm 1993; Suppl 2: 215-222.

8. Crystal HA, Dickson D, Davies P, Masur D, Grober E, Lipton RB. The relative frequency of "dementia of unknown etiology" increases with age and is nearly $50 \%$ in nonagenarians. Arch Neurol 2000; 57: 713-719.

9. De Reuck J, Deramecourt V, Cordonnier C, Leys D, Maurage CA, Pasquier $F$. The impact of cerebral amyloid angiopathy on the occurrence of cerebrovascular lesions in demented patients with Alzheimer features: a neuropathological study. Eur J Neurol 2011; 18: 913- 918.

10. De Reuck J, Deramecourt V, Cordonnier C, Leys D, Pasquier F, Maurage CA. Prevalence of small cerebral bleeds in patients with a neurodegenerative dementia: A neuropathological study. J Neurol Sci 2011; 300: 63-66.

11. De Reuck, Deramecourt V, Cordonnier C, Auger F, Durieux N, Bordet R, Maurage CA, Leys D, Pasquier F. Detection of microbleeds in post-mortem brains of patients with frontotemporal lobar degeneration: a 7.0-tesla magnetic resonance imaging study with neuropathological correlates. Eur J Neurol 2012; 19: 1355-1360.

12. De Reuck J, Deramecourt V, Cordonnier C, Leys D, Pasquier F, Maurage CA. Cerebrovascular lesions in patients with frontotemporal lobar degeneration: a neuropathological study. Neurodegenerative Dis 2012; 9: 170-175.

13. De Reuck J, Deramecourt V, Cordonnier C, Leys D, Pasquier F, Maurage CA. Prevalence of cerebrovasular lesions in patients wity Lewy body dementia: a neuropathological study. Clin Neurol Neurosurg 2013; 115: 1094-1097.

14. De Reuck J, Deramecourt V, Auger F, Durieux N, Cordonnier C, Devos D, Defebvre L, Moreau C, Caparrros-Lefebvre D, Bordet R, Maurage CA, Pasquier F, Leys D. Post-mortem 7.0-tesla magnetic resonance study of cortical microinfarcts in neurodegenerative 
diseases and vascular dementia with neuropathological correlates. J Neurol Sci 2014; 15: 85-89.

15. De Reuck J, Auger F, Durieux N, Cordonnier C, Deramecourt V, Lebert F, Leys D, Pasquier F, Maurage CA, Bordet R. Detection of cortical microbleeds in postmortem brains of patients with Lewy body dementia: a 7.0-tesla magnetic resonance imaging study with neuropathological correlates. Eur Neurol 2015; 74: 158-161.

16. De Reuck J, Deramecourt V, Cordonnier C, Pasquier F, Leys D, Maurage CA, Bordet R. The incidence of post-mortem neurodegenerative and cerebrovascular pathology in mixed dementia. J Neurol Sci 2016; 369: 164-166.

17. De Reuck J, Deramecourt V, Auger F, Durieux N, Maurage CA, Pasquier F, Cordonnier C, Leys D, Bordet R. Cerebrovascular lesions in mixed neurodegenerative dementia: a neuropathological and magnetic resonance study. Eur Neurol 2017; 78: 1-5.

18. De Reuck J, Auger F, Durieux N, Deramecourt V, Maurage CA, Cordonnier C, Pasquier F, Leys D, Bordet R. Frequency and topography of small cerebrovascular lesions in vascular and in mixed dementia: a post-mortem 7-tesla magnetic resonance imaging study with neuropathological correlates. Folia Neuropathol 2017; 55: 31-37.

19. De Reuck J, Devos D, Moreau C, Auger F, Durieux N, Deramecourt V Pasquier F, Maurage C-A, Cordonnier C, Leys D. Bordet R. Topographic distribution of brain iron deposition and small cerebrovasular lesions in amyotrophic lateral sclerosis and in frontotemporal lobar degeneration: a post-mortem 7.0 tesla magnetic resonance imaging study with neuropathological correlates. Acta Neurol Belg 2017: 117: 873-878.

20. Ellis RJ, Olichney JM, Thal LJ, Mirra SS, Morris JC, Beekly D, Heyman A. Cerebral amyloid angiopathy in the brains of patients with Alzheimer's disease: the CERAD experience, Part XV. Neurology 1996; 46; 1592-1596.

21. Gorelick PB, Scuteri A, Black SE, Decarli C, Greenberg SM, ladecola C, Launer LJ, Laurent S, Lopez OL, Nyenhuis D, Petersen RC, Schneider JA, Tzourio C, Arnett DK, Bennett DH, Chui HC, Higashida RT, Lindquist R, Nilsson PM, Roman GC, Sellke FW, Seshadri S; American Heart Association Stroke Council, Council on Epidemiology and Prevention, Council on Cardiovascular Nursing, Council on Cardiovascular Radiology and Intervention, and Council on Cardiovascular Surgery and Anesthesia. Vascular contributions to cognitive impairment and dementia: a statement for healthcare professionals from the American heart association/American stroke association. Stroke 2011; 42: 2672-2713.

22. Haglund M, Kalaria R, Sladz JY, Englund E. Differential deposition of amyloid beta peptides in cerebral amyloid angiopathy associated with Alzheimer's disease and vascular dementia. Acta Neuropathol 2006; 111: 430-435.

23. Hauw JJ, Daniel SE, Dickson D, Horoupian DS, Jellinger K, Lantos PL, McKee A, Tabaton M, Litvan I. Preliminary NINDS neuropathological criteria for Steele-Richardson-Olszewski syndrome (progressive supranuclear palsy). Neurology 1994; 44: 2015-2019.

24. Irwin DJ, Grossman M, Weintraub D, Hurtig HI, Duda JE, Xie SX, Lee EB, Van Deerlin VM, Lopez OL, Kofler JK, Nelson PT, Jicha GA, Woltjer R, Quin JF, Kaye J, Leverenz JB, Tsuang D, Longfellow K, Yearout D, Kukull W, Keene CD, Montine TJ, Zabetian CP, Trojanowski JQ. Neuropathological and genetic correlates of survival and dementia onset in synucleinopathies. A retrospective analysis. Lancet Neurol 2017; 15: 55-65.

25. Jellinger KA, Attems J. Prevalence of dementia disorders in the oldest-old: an autopsy study. Acta Neuropathol 2010; 119: 421433.

26. Jellinger KA, Attems J. Chalanges of multimorbidity of the aging brain: a critical update. J Neural Transm 2015; 122: 505-5021.

27. Kapasi A, DeCarli C, Schneider JA. Impact of multiple pathologies on the threshold for clinically overt dementia. Acta Neuropathol 2017; 134: 171-186

28. Kotzbauer PT, Trojanowski JQ, Lee VM. Lewy body pathology in Alzheimer's disease. J Mol Neurosci 2001; 17: 225-232.

29. Langa KM, Foster NL, Larson EB. Mixed dementia: emerging concepts and therapeutic implications. JAMA 2004; 292: 2901-2908.

30. McAleese KE, Alafuzoff I, Charidimou A, De Reuck J, Grinberg LT, Hainsworth AH, Hortobagyi T, Ince P, Jellinger K, Gao J, Kalaria RN, Kovacs GG, Kövari E, Love S, Popovic M, Skrobot O, Taipa R, Thal DR, Werring D, Wharton SB, Attems J. Post-mortem assessment in vascular dementia: advances and aspirations. BMC Med 2016; 14: 129.

31. McAleese KE, Walker L, Erskine D, Thomas AJ, McKeith IG, Attems J. TDP-43 pathology in Alzheimer's disease, dementia with Lewy bodies and ageing. Brain Pathol 2017; 27: 472-479.

32. McKeith IG, Galasko D, Kosaka K, Perry EK, Dickson DW, Hansen LA, Salmon DP, Lowe J, Mirra SS, Byrne EJ, Lennox G, Quinn NP, Edwardson JA, Ince PG, Bergeron C, Burns A, Miller BL, Lovestone S, Collerton D, Jansen EN, Ballard C, de Vos RA, Wilcock GK, Jellinger KA, Perry RH. Consensus guidelines for the clinical and pathologic diagnosis of dementia with Lewy bodies (DLB): report of the consortium on DLB international workshop. Neurology 1996; 47: 1113-1124.

33. Nelson PT, Head E, Schmitt FA, Davis PR, Neltner JH, Jicha GA, Abner EL, Smith CD, Van Eldik LJ, Kryscio RJ, Scheff SW. Alzheimer's disease is not "brain aging": neuropathological, genetic, and epidemiological human studies. Acta Neuropathol 2011; 121: 571-587.

34. Rahimi J, Kovacs GG. Prevalence of mixed pathology in the aging brain. Alzheimers Res Ther 2014; 6: 82.

35. Raz L, Koefel J, Bhaskar K. The neuropathology of cerebrovascular mechanisms of dementia. J Cereb Blood Flow Metab 2016; 36: 172-186.

36. Schneider JA, Arvanitakis Z, Bang W, Bennett DA. Mixed brain pathologies account for most dementia cases in community-dwelling older persons. Neurology 2007; 69: 2197-2204.

37. Wakisaka Y, Furuta A, Tanizaki Y, Kiyohara Y, lida M, Iwaki T. Age-associated prevalence and risk factors of Lewy body pathology in a general population: the Hisayama study. Acta Neuropathol 2003; 106: 374-382

38. Wu E, Lipton RB, Dickson DW. Amyloid angiopathy in diffuse Lewy body disease. Neurology 1992; 42: 2131-2135. 